\title{
Vrednotenje pridelka koruze za sonarave oblike kmetovanja
}

\author{
Borut BOHANEC ${ }^{1}$, Tanja BOHINC ${ }^{1}$, Filip VUČAJNK ${ }^{1}$
}

Received May 30, 2017; accepted September 15, 2017.

Delo je prispelo 30. maja 2017, sprejeto 15. septembra 2017.

\section{IZVLEČEK}

Sodobne hibridne sorte koruze že več desetletij prevladujejo tako v Sloveniji kot drugod po svetu. V Sloveniji je v pridelavi ohranjenih le malo starih populacijskih sort, 614 pa jih vzdržujemo v sklopu programa Slovenska rastlinska genska banka na Biotehniški fakulteti Univerze $\mathrm{v}$ Ljubljani. Izboljšanje populacijskih sort $\mathrm{z}$ rekurentno selekcijo je mogoče in ima lahko $\mathrm{v}$ primeru posebnih lastnosti svoje mesto $\mathrm{v}$ tržni pridelavi. V sortnih poskusih $\mathrm{v}$ osrednji Sloveniji in $\mathrm{v}$ Beli krajini smo proučevali izbrane stare populacije koruze. Pridelki koruze so bili na obeh lokacijah in v obeh letih močno odvisni od genotipa. Populacije 'Rdeča bohinjka' in delno 'Rumena bohinjka', podobno pa tudi 'LJ 180' so imele majhne pridelke, bile pa so med najbolj ranimi, medtem ko sta imeli sodobni hibridni sorti, 'P 9074' in 'Ronaldinio KWS', pričakovano največji pridelek. Pridelek populacije 'P 9074' je bil na laboratorijskem polju Biotehniške fakultete skoraj dvakrat večji od druge najboljše populacije poltrdinke 'Metliška Plut'. Prav ta populacija pa se je v vseh štirih poskusih pokazala kot zelo primerna za nadaljno vzdrževanje in prijavo sorte, saj bi lahko $\mathrm{v}$ manj intenzivni pridelavi pomenila ustrezno alternativo hibridnim sortam.

Ključne besede: pridelek koruze; starejše akcesije; genska banka; populacijske sorte

\section{ABSTRACT \\ EVALUATION OF MAIZE CROPS FOR SUSTAINABLE FARMING}

Modern hybrid maize varieties dominated for several decades both in Slovenia and elsewhere in the world. The production is maintained only of few landrace populations, but some are maintained at Slovenian Gene Bank. Improvement of local varieties is possible by recurrent selection and may in the case of their specific characteristics deserve their cultivation for specific purposes. Presented experiments have been conducted to characterize selected old Slovenian accessions in two regions - in central Slovenia and in Bela Krajina. Yields of corn at both locations and both years were significantly depending on the genotype. 'Rdeča Bohinjka' and partially 'Rumena Bohinjka' and, similarly, the 'LJ 180' had a predominantly low yields but were also the earliest, while modern hybrid variety 'P 9074' and 'Ronaldinio KWS ' had the expected highest yield. Yield of 'P 9074' grown at the Laboratory field of the Biotechnical Faculty was almost twice higher than the second best accession 'Metliška Plut'. However it is this semi-flint accessions 'Metliška Plut' that proved very suitable at all four experiments and is recommended for further maintenance and varietal testing as it can serve as appropriate alternative in a less intensive production.

Key words: maize yield; older accessions; gene bank; cross pollinated varieties

\section{UVOD}

Pridelovanje koruze ima dominantno vlogo v slovenskem kmetijstvu že več desetletij. Kmalu po drugi svetovni vojni so se pričele pospešeno pridelovati hibridne sorte koruze, s tem pa se je genofond lokalnih populacij pričel hitro zmanjševati. Zato je profesor Franc Mikuž že v 50. letih dvajsetega stoletja pričel z zbiranjem lokalnih populacij, ki jih zdaj hranimo $\mathrm{v}$ slovenski rastlinski genski banki (Rozman 2012). Zbran material je bil tudi osnova žlahtnjenja domačih hibridnih sort koruze. Iz tega sklopa so tri med njimi, 'LJ-180', 'LJ 220W' in 'LJ-275t' na seznamu avtohtonih in tradicionalnih sort kmetijskih rastlin (Uradni list RS, št. $33 / 04$ in 110/04).

Sodobne hibridne sorte koruze po pridelkih zvečine močno prekašajo starejše populacijske sorte (Kutka,

1 University of Ljubljana, Biotechnical Faculty, Agronomy Department, Jamnikarjeva ulica 101, SI-1111 Ljubljana, Slovenia, corresponding author: borut.bohanec@bf.uni-lj.si 
2011). Vendar avtor meni, da je izboljšanje populacijskih sort $\mathrm{z}$ rekurentno selekcijo mogoče in ima lahko v primeru posebnih lastnosti svoje mesto v tržni pridelavi. Več avtorjev pa poudarja pomen lokalnih populacij kot virov določenih lastnosti primernih za uporabo v žlahtnjenju sodobnih sort. Tako denimo Rebilla in sod. (1998) in Shelton in Tracy (2015) poudarjajo uporabnost populacijskih sort sladke koruze za žlahtnjenje in ki bi bile primerne za pridelavo $\mathrm{v}$ severnih območjih Evrope in ZDA. Muntean in sod.
(2012) pa poudarjajo uporabo inbridiranih linij pridobljenih iz lokalnih populacij za pridelovanje sintetičnih kultivarjev koruze prilagojenih lokalnim rastnim razmeram.

Izhodišče naše raziskave je bilo ugotoviti, ali je mogoče identificirati lokalne populacije koruze primerne za ekstenzivni način kmetovanja oziroma možnost njihove prijave kot sorte $\mathrm{z}$ dovoljenjem za trženje.

\section{MATERIALI IN METODE}

\subsection{Poskus v letu 2015}

Setev koruze je v letu 2015 potekala na dveh lokacijah, v Jabljah na Infrastrukturnem centru Kmetijskega inštituta Slovenije (kjer pridelava koruze poteka na konvencionalen način) in na ekološkem posestvu $\mathrm{v}$ Krasincu. Na obeh lokacijah smo zasnovali poskus z 9 različnimi populacijami koruze, in sicer 'Lj-180', 'LJ- 275t', 'Rdeča bohinjka', 'Rumena bohinjka', 'Metliška Plut', 'Štajerska bela', 'Metliška rdeča', 'Prekmurska dolga', 'Belokranjska trdinka'. Poskus je potekal v treh blokih, znotraj katerih smo naključno razporedili različne populacije koruze. V Jablah smo koruzo sejali 8. maja, v Krasincu pa 30. aprila 2015.

Tabela 1: Seznam vključenih akcesij

Table 1: List of tested acessions

\begin{tabular}{|l|l|}
\hline Akcesija & Izvor \\
\hline & \\
\hline 'Rdeča bohinjka' & populacija SRGB 3299 \\
\hline 'Rumena bohinjka' & populacija SRGB 3299 \\
\hline 'Metliška Plut' & populacija SRGB 7081 \\
\hline 'Štajerska bela' & populacija SRGB 3315 \\
\hline 'Metliška rdeča' & populacija SRGB 3307 \\
\hline 'Prekmurska dolga' & populacija SRGB 3252 \\
\hline 'Belokranjska trdinka' & populacija. SRGB 3309 \\
\hline 'LJ 180' & F1 hibrid Biotehniška fakulteta \\
\hline 'Lj 275t' & F1 hibrid Biotehniška fakulteta \\
\hline 'Ronaldinio KWS' & F1 hibrid KWS \\
\hline 'P 9074' & F1 hibrid DuPont Pioneer \\
\hline
\end{tabular}

Ocenjevali smo naslednje parametre: čas do metličenja, vlago ob spravilu koruze in pridelek koruze (ob $14 \%$ vlagi) v t/ha. Spravilo koruze je v Jabljah potekalo 22. oktobra, v Krasincu pa 28. oktobra.

\subsection{Poskus v letu 2016}

Devet različnih populacij koruze smo v letu 2016 posejali na dveh različnih lokacijah, in sicer na Laboratorijskem polju Biotehniške fakultete Univerze $\mathrm{v}$ Ljubljani ter na ekološkem posestvu $\mathrm{v}$ Krasincu. V poskus smo vključili sorti 'LJ-180', 'LJ-275t' in populacije 'Rdeča bohinjka', 'Rumena bohinjka', 'Metliška Plut', 'Štajerska bela', 'Metliška rdeča', 'Prekmurska dolga', 'Belokranjska trdinka'. Poleg prej omenjenih smo za primerjavo posadili še hibrid 'P074
F1' na Laboratorijskem polju Biotehniške fakultete, in hibrid 'Ronaldinio' na ekološkem posestvu v Krasincu (Tabela 1).

V letu 2016 smo poleg pridelka ocenjevali še višino rastlin $(\mathrm{v} \mathrm{cm})$ in poleganje koruze. $\mathrm{Na}$ obeh lokacijah smo ocenjevali okuženost rastlin s koruzno progavostjo (Setosphaeria turcica (Luttr.) K.J. Leonard \& Suggs). Uporabili smo ocenjevalno lestvico po Fullerton-u (1982), kjer ocena 4 predstavlja močno okužbo, ocena 3 pa zmerno okužbo. Poleganje rastlin smo ocenili $\mathrm{z}$ indeksom poleglosti, izraženim z vrednostjo od $0-4$, kjer je bil indeks 0 nepoleglo, indeks 1 do $33 \%$ poleglo, indeks 234 do $66 \%$ poleglo, indeks 367 do $99 \%$ poleglo in indeks 4 povsem poleglo glede na vizualno oceno. 
Poskus je bil zasnovan v treh blokih, znotraj katerih smo naključno razporedili obravnavan populacije koruze. $\mathrm{Na}$ Laboratorijskem polju smo koruzo sadili 4. maja 2016; na ekološkem posestvu v Krasincu pa 26. aprila 2016.

\subsection{Statistična analiza podatkov}

Rezultate poskusa smo statistično ovrednotili s programom Statgraphics Centurion XVI (Statgraphics
Centurion, 2009). Razlike v pridelku med posameznimi populacijami smo ovrednotili $\mathrm{z}$ analizo variance (ANOVA) in Duncanovim ter Student Newman Keulsovim testom mnogoterih primerjav $(\mathrm{P} \leq 0,05)$. Razlike v obsegu okužbe $\mathrm{s}$ koruzno progavostjo med populacijami koruze smo ovrednotili $\mathrm{z}$ analizo variance (ANOVA) in Student Newman Keulsovim testom mnogoterih primerjav $(\mathrm{P} \leq 0,05)$.

\section{REZULTATI}

\subsection{Poskus v letu 2015}

Akcesije so se med seboj razlikovale po ranosti, kar je razvidno iz ocene pojava metličenja (Jablje). Najzgodnejši je bil hibrid 'LJ 180', najpoznejša pa populacija 'Belokranjska trdinka'. Podobno so se na tej lokaciji akcesije razlikovale $\mathrm{v}$ vsebnosti vlage $\mathrm{v}$ zrnju ob spravilu, kjer je imel hibrid 'LJ 180' najmanjšo, 'Belokranjska trdinka' pa največjo (Tabela 2).
V Jabljah sta imeli značilno najmanjši pridelek populaciji 'Rdeča bohinjka' (3,87 t/ha) in 'Rumena bohinjka' (3,95 t/ha). Ob spravilu smo pri populaciji 'Rdeča bohinjka' zabeležili $26,3 \%$ vlage v zrnju, pri populaciji 'Rumena bohinjka' pa 26,6\%. Signifikatno največji pridelek je imela populacija 'Metliška Plut' $(7,7$ t/ha). Vlaga zrnja ob spravilu je znašala $27,2 \%$ (Tabela 2).

Table 2: Čas metličenja, vlaga in pridelek po posameznih akcesijah koruze na lokaciji v Jablah (2015)

Table 2: Days to tasseling, seed moisture and yield according to accessions on location Jable (2015)

\begin{tabular}{|l|l|l|l|}
\hline Akcesija & $\begin{array}{l}\text { Dnevi do } \\
\text { metličenja }\end{array}$ & $\begin{array}{l}\text { Vlaga ob } \\
\text { spravilu (\%) }\end{array}$ & $\begin{array}{l}\text { Pridelek } \\
\text { ob 14\% } \\
\text { vlagi t/ha }\end{array}$ \\
\hline 'LJ 180' & 49 & 27,8 & $6,35 \mathrm{bc}^{*}$ \\
\hline 'Rdeča bohinjka' & 51 & 26,3 & $3,87 \mathrm{a}$ \\
\hline 'Lj 275t' & 52 & 29,1 & $6,86 \mathrm{~cd}$ \\
\hline 'Rumena bohinjka' & 52 & 26,6 & $3,95 \mathrm{a}$ \\
\hline 'Metliška Plut' & 56 & 27,2 & $7,70 \mathrm{~d}$ \\
\hline 'Štajerska bela' & 57 & 30,9 & $5,56 \mathrm{~b}$ \\
\hline 'Metliška rdeča' & 59 & 29,9 & $5,56 \mathrm{~b}$ \\
\hline 'Prekmurska dolga' & 59 & 29,9 & $5,85 \mathrm{bc}$ \\
\hline 'Belokranjska trdinka' & 61 & 32,8 & $6,84 \mathrm{~cd}$ \\
\hline
\end{tabular}

* različne črke v stolpcu pomenijo statistično značilno razliko po Duncanu $(\mathrm{P} \leq 0,05)$

V Krasincu je imela značilno najmanjši pridelek populacija 'Rdeča bohinjka' (2,60 t/ha). Vlaga ob spravilu je znašala $28,4 \%$. Značilno največji pridelek je imela populacija 'Metliška Plut' (4,12 t/ha in 29,6 \% vlage v zrnju) (Tabela 3). 
Tabela 3: Delež vlage v zrnju ob spravilu ter pridelek po posameznih akcesijah koruze na lokaciji v Krasincu (2015)

Table 3: Seed moisture content and yield of maize populations evaluated on location Krasinec (2015)

\begin{tabular}{|l|l|l|}
\hline Akcesija & $\begin{array}{l}\text { Vlaga ob } \\
\text { spravilu }\end{array}$ & $\begin{array}{l}\text { Pridelek } \\
\text { ob 14 \% } \\
\text { vlagi t/ha }\end{array}$ \\
\cline { 2 - 4 } 'LJ-180' & 30,9 & $3,27 \mathrm{bc} *$ \\
\hline 'Rdeča bohinjka' & 28,4 & $2,60 \mathrm{ab}$ \\
\cline { 2 - 3 } 'LJ -275t' & 27,6 & $3,61 \mathrm{bc}$ \\
\hline 'Rumena bohinjka' & 26,2 & $2,13 \mathrm{a}$ \\
\hline 'Metliška Plut' & 29,6 & $4,12 \mathrm{c}$ \\
\hline 'Štajerska bela' & 29,5 & $3,10 \mathrm{abc}$ \\
\hline 'Metliška rdeča' & 29,8 & $3,60 \mathrm{bc}$ \\
\hline 'Prekmurska dolga' & 29,0 & $3,29 \mathrm{bc}$ \\
\hline 'Belokranjska trdinka' & 32,3 & $3,62 \mathrm{bc}$ \\
\hline
\end{tabular}

* različne črke v stolpcu pomenijo statistično značilno razliko po Duncanu $(\mathrm{P} \leq 0,05)$

\subsection{Poskus v letu 2016}

Na Laboratorijskem polju Biotehniške fakultete je imela značilno najmanjši pridelek zrnja populacija 'Rdeča bohinjka' (1,4 t/ha). Rastline omenjene populacije so bile poleg rastlin populacije 'Rumena bohinjka' $(169 \mathrm{~cm})$ značilno najnižje, $\mathrm{s}$ povprečno višino $176 \mathrm{~cm}$ (Tabela 4).
Pridelek zrnja je bil značilno največji pri populacijah 'Metliška Plut' (3,52 t/ha) in 'P 9074' (6,5 t/ha). Rastline populacije 'Metliška Plut' so bile $\mathrm{v}$ povprečju visoke $265 \mathrm{~cm}$, rastline hibrida 'P 9074' pa $234 \mathrm{~cm}$. Sorti z najvišjim pridelkom sta dosegli indeks poleganja koruze 0,4 . 29,5\% vlage v zrnju smo namerili ob spravilu pri populaciji 'Metliška Plut'; 26,3 \% vlaga pa je bila zabeležena pri hibridu 'P 9074'(Tabela 4).

Tabela 4: Višina rastlin, indeks poleglosti, vlaga ob spravilu in pridelek po posameznih akcesijah koruze na njivi na Laboratorijskem polju Biotehniške fakultete Ljubljana (UL) (2016)

Table 4: Plant height, lodging index, seed water content moisture and yield according to accessions on location at Laboratory field of Biotechnical Faculty Ljubljana (2016)

\begin{tabular}{|l|l|l|l|l|}
\hline Akcesija & $\begin{array}{l}\text { Višina rastlin } \\
(\mathrm{cm})\end{array}$ & $\begin{array}{l}\text { Indeks } \\
\text { poleglosti } \\
(0-4)\end{array}$ & $\begin{array}{l}\text { Vlažnost } \\
\text { zrnja ob ob } \\
\text { spravilu }\end{array}$ & $\begin{array}{l}\text { Pridelek } \\
\text { ob 14\% } \\
\text { llagi kg/ha }\end{array}$ \\
\hline 'Rdeča bohinjka' & $176 \mathrm{a}^{*}$ & 1,7 & 25,1 & $1,47 \mathrm{a}$ \\
\hline 'Rumena bohinjka' & $169 \mathrm{a}$ & 3,0 & 22,6 & $1,62 \mathrm{a}$ \\
\hline 'Prekmurska dolga' & $214 \mathrm{bcd}$ & 1,7 & 27,6 & $2,06 \mathrm{ab}$ \\
\hline 'Štajerska bela' & $187 \mathrm{ab}$ & 1,7 & 30,1 & $2,4 \mathrm{abc}$ \\
\hline 'Belokranjska trdinka' & $258 \mathrm{e}$ & 0,4 & 34,8 & $2,84 \mathrm{bc}$ \\
\hline 'LJ 180' & $209 \mathrm{bc}$ & 2,0 & 22,5 & $2,95 \mathrm{bc}$ \\
\hline 'Metliška rdeča' & $250 \mathrm{e}$ & 0,4 & 31,1 & $3,03 \mathrm{bc}$ \\
\hline 'LJ 275t & $246 \mathrm{de}$ & 2,0 & 28,3 & $3,30 \mathrm{bc}$ \\
\hline 'Metliška Plut' & $265 \mathrm{e}$ & 0,4 & 29,5 & $3,52 \mathrm{c}$ \\
\hline 'P 9074' & $234 \mathrm{cde}$ & 0,4 & 26,3 & $6,50 \mathrm{~d}$ \\
\hline
\end{tabular}

* različne črke v stolpcu pomenijo statistično značilno razliko po Duncanu $(\mathrm{P} \leq 0,05)$

Največji povprečni pridelek $\mathrm{v}$ Krasincu je imel hibrid 'Ronaldinio KWS' (7,28 t/ha), medtem ko je imel značilno najmanjšega zgodnji hibrid 'Lj 180' (1,78 t/ha).
Pridelek zrnja populacije 'Metliška Plut' je znašal $5,49 \mathrm{t} / \mathrm{ha}$. Rastline slednje so bile $\mathrm{v}$ povprečju visoke 2,84 m (Tabela 5). 
Tabela 5: Višina rastlin, indeks poleglosti, vlaga zrnja ob spravilu in pridelek zrnja po posameznih akcesijah koruze na njivi v Krasincu (2016)

Table 5: Plant height, lodging, seed moisture and grain yield according to accessions on location in Krasinec (2016)

\begin{tabular}{|l|l|l|l|l|}
\hline Akcesija & $\begin{array}{l}\text { Višina rastlin } \\
(\mathrm{cm})\end{array}$ & $\begin{array}{l}\text { Indeks } \\
\text { poleglosti } \\
(0-4)\end{array}$ & $\begin{array}{l}\text { Vlažnost } \\
\text { zrnja ob } \\
\text { spravilu }\end{array}$ & $\begin{array}{l}\text { Pridelek } \\
\text { ob 14 \% } \\
\text { vlagi t/ha }\end{array}$ \\
\hline 'Rdeča bohinjka' & $215 \mathrm{a}$ & 0,33 & 24,1 & $2,09 \mathrm{a}$ \\
\hline 'Rumena bohinjka' & $238 \mathrm{ab}$ & 0,33 & 23,5 & $5,48 \mathrm{bc}$ \\
\hline 'Prekmurska dolga' & $300 \mathrm{~d}$ & 0,33 & 26,6 & $6,70 \mathrm{bc}$ \\
\hline 'Štajerska bela' & $245 \mathrm{ab}$ & 0,33 & 28,1 & $5,69 \mathrm{bc}$ \\
\hline 'Belokranjska trdinka' & $298 \mathrm{~d}$ & 0,33 & 30,3 & $6,69 \mathrm{c}$ \\
\hline 'LJ 180' & $216 \mathrm{a}$ & 0,33 & 23,1 & $1,78 \mathrm{a}$ \\
\hline 'Metliška rdeča' & $298 \mathrm{~d}$ & 0,33 & 26,0 & $6,43 \mathrm{bc}$ \\
\hline 'LJ 275t & $257 \mathrm{bc}$ & 0,33 & 23,7 & $4,58 \mathrm{~b}$ \\
\hline 'Metliška Plut' & $284 \mathrm{~cd}$ & 0,33 & 24,7 & $5,49 \mathrm{bc}$ \\
\hline 'Ronaldinio KWS' & $252 \mathrm{~b}$ & 0,33 & 22,9 & $7,28 \mathrm{c}$ \\
\hline
\end{tabular}

* različne črke v stolpcu pomenijo statistično značilno razliko po Duncanu $(\mathrm{P} \leq 0,05)$

V letu 2016 smo na obeh lokacijah ocenjevali tudi obseg okužbe s koruzno progavostjo (S. turcica). Na Laboratorijskem polju Biotehniške fakultete je bila povprečna ocena značilno največja pri populaciji
'Prekmurska dolga' $(3,00 \pm 0,15)$ in hibridu 'LJ 180' $(2,93 \pm 0,13)$. Povprečni obseg okužbe je bil značilno najmanjši pri hibridu 'P 9074' (1,93 $\pm 0,09)$, za populacijo 'Metliška Plut' pa je znašal 2,33 $\pm 0,14$ (Slika 1).

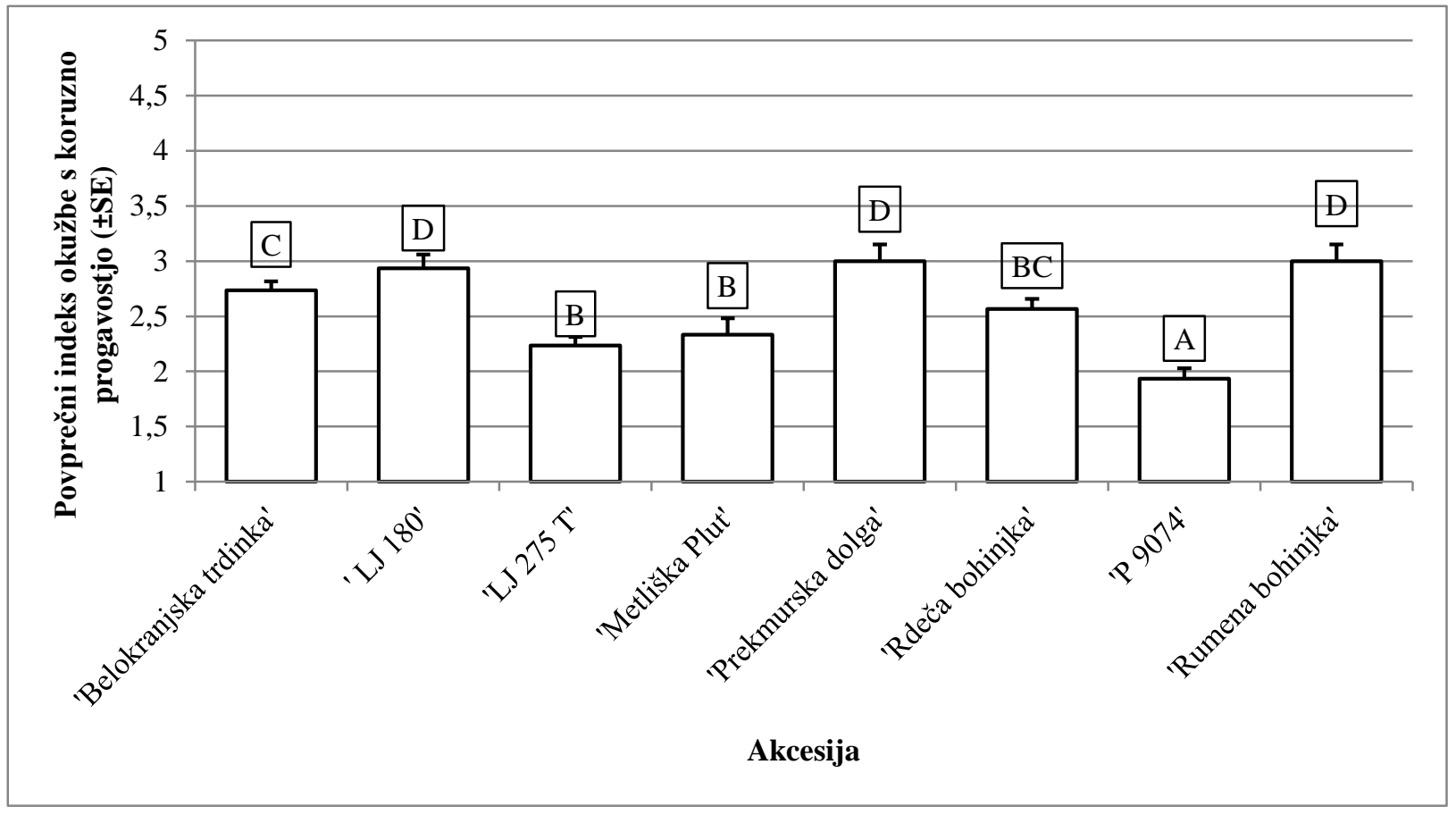

Slika 1: Povprečni indeks okužbe s koruzno progavostjo (Setosphaeria turcica (Luttr.) K.J. Leonard \& Suggs) ( \pm SE) na Laboratorijskem polju Biotehniške fakultete Ljubljana (2016)

Figure 1: Average index of infection by northern leaf blight (Setosphaeria turcica (Luttr.) K.J. Leonard \& Suggs,) $( \pm \mathrm{SE})$ at Laboratory field of Biotechnical Faculty Ljubljana (2016)

* različne črke pomenijo statistično značilno razliko po Duncanu $(\mathrm{P} \leq 0,05)$ 
V Krasincu je bil povprečni obseg okužbe signifikantno največji pri populaciji 'Rumena bohinjka' $(4,0 \pm 0,0)$. Hibrid 'LJ 180' je imel povprečni indeks okuženosti 3,4 $\pm 0,13$; populacija 'Metliška Plut' pa $2,8 \pm 0,10$. Najmanjši povprečni indeks okuženosti je imel hibrid 'Ronaldinio KWS' (1,66 $\pm 0,12)$. (Slika 2).

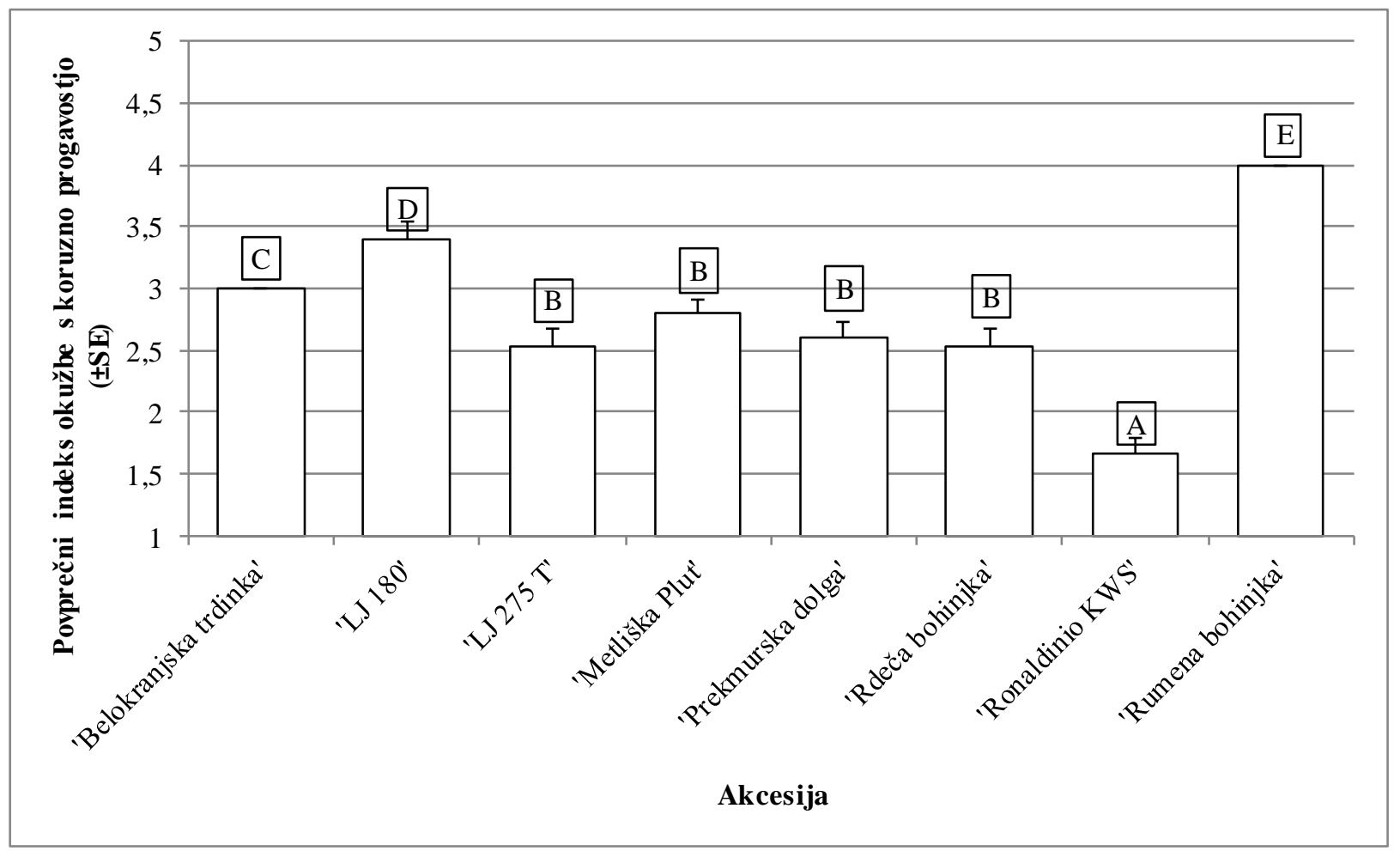

Slika 2: Povprečni indeks okužbe s koruzno progavostjo (Setosphaeria turcica (Luttr.) K.J. Leonard \& Suggs) ( \pm SE) v Krasincu (2016)

Figure 2: Average index of infection by northern leaf blight (Setosphaeria turcica (Luttr.) K.J. Leonard \& Suggs) $( \pm$ SE) at Krasinec (2016)

* različne črke pomenijo statistično značilno razliko po Duncanu $(\mathrm{P} \leq 0,05)$

\section{RAZPRAVA}

Pridelki koruze so bili na obeh lokacijah in v obeh letih močno odvisni od genotipa. 'Rdeča bohinjka' in delno 'Rumena bohinjka', podobno pa tudi 'LJ 180' so imele pretežno majhne pridelke, so pa bile tudi med najbolj ranimi, torej je bil manjši pridelek pričakovan. Sodobni hibridni sorti 'P 9074' in 'Ronaldinio KWS' sta imeli pričakovano največji pridelek. Pridelek populacije 'P
9074' je bil na Laboratorijskem polju Biotehniške fakultete skoraj dvakrat večji od populacije 'Metliška Plut'. Prav slednja je pokazala zadovoljive rezultate na vseh poskusih in je zato lahko primerna za lokalno pridelavo tudi v ekološkem načinu pridelave. 'Metliška Plut'je raznolika glede na dolžino in obarvanost storžev (Slika 3), kar pa bi lahko z nadaljnjo selekcijo izboljšali. 


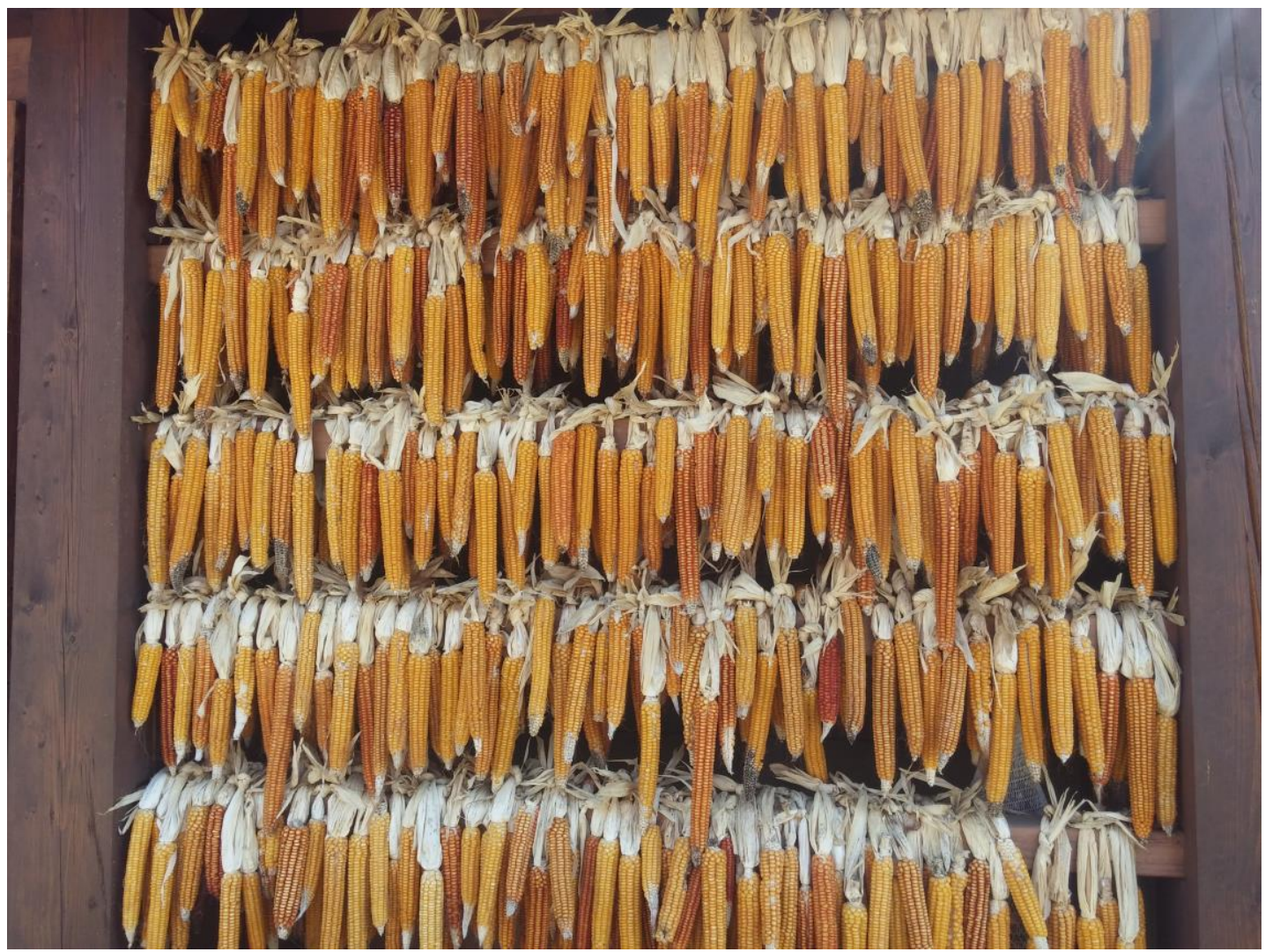

Slika 3: Variabilnost akcesije 'Metliška Plut' pri vzdrževalcu (Aleš Plut, Cerovec 17, Semič) (pridelek 2016). Figure 3: Variability of accession 'Metliška Plut' at maintainers site (Aleš Plut, Cerovec 17, Semič) (yield 2016)

Rezultati naše raziskave kažejo, da se lokalne populacije različno odzivajo na abiotične in biotične dejavnike. Andjelković in sod. (2014) denimo navajajo, da so bile različne akcesije koruze različno odporne na sušo.

Ugotovili smo, da obstajajo razlike med posameznimi populacijami koruze glede na pridelovalne sisteme. V Osrednji Sloveniji smo koruzo gojili na konvencionalen način, medtem ko smo v jugovzhodni Sloveniji poskus z različnimi genotipi koruze zasnovali na ekološki kmetiji. V obeh letih poskusa je po pridelku zrnja med populacijami izstopala 'Metliška Plut'. V drugem letu poskusa je bil njen pridelek primerljiv s hibridnimi sortami v obeh letih poskusa. V 2016 smo raziskavo nadgradili, saj smo poleg pridelka spremljali tudi indeks okuženosti s koruzno progavostjo. Hibridni sorti sta bili na obeh lokacijah najmanj dovzetni na širjenje koruzne progavosti. Da so hibridne sorte koruze manj dovzetne za napad škodljivih organizmov, v svojemu delu navajajo Beaver in sod. (2011).

Indeks okuženosti s koruzno progavostjo je bil manjši na poskusu v osrednji Sloveniji, kar med drugim lahko pripišemo dobri kmetijski praksi.

\section{ZAKLJUČEK}

Poskusi uporabne vrednosti slovenskih populacij in sort koruze $\mathrm{v}$ dveh različnih regijah so pokazali, da lokalne populacije po pridelku in odpornostjo proti boleznim niso neposredno konkurenčne sodobnim hibridnim sortam. Vsekakor pa je potrebno poudariti, da zlasti populacija poltrdinke 'Metliška Plut' odstopa od ostalih in je primerna za pridelavo na izbranih lokacijah. Akcesijo že razmnožujemo in pripravljamo za vpis na sortno listo. 


\section{ZAHVALA}

Raziskava je bila izvedena v sklopu projekta V4-1313 'Vzpostavitev sistema vzdrževalne selekcije in pridelave semenskega materiala kmetijskih rastlin za sonaravne oblike kmetovanja'. Zahvaljujemo se izr. prof. dr. Ludviku Rozmanu za aktivnost pri štartu projekta in dolgoletnemu delu na genskih virih koruze.

\section{VIRI}

Andjelkovic, V., Kravic, N., Ignjatovic-Micic, D., Dumanovic, Z., Vancetovic, J. (2014). Estimation of drought tolerance among maize landraces from minicore collection. Genetika-Belgrade, 46(3), 775-788. doi:10.2298/GENSR1403775A

Beaver, J.S., Brunner, B.R., Armstrong, A. (2011). Release of sweet corn (Zea mays L.) open-pollinated cultivar 'Suresweet 2011'. Journal of Agriculture of the University of Puerto Rico, 95(1/2):105-110.

Fullerton, R.A. (1982). Assessment of leaf damage caused by northern leaf blight in maize, New Zealand Journal of Experimental Agriculture, 10, 313-316. doi:10.1080/03015521.1982.10427890

Kutka, F. (2011). Open-pollinated vs. hybrid maize cultivars. Sustainability, 3, 1531-1554. doi:10.3390/su3091531
Muntean, L., Has, I., Has, V., Gulea, A. (2012). Comparison between some corn synthetic populations obtained from Transylvanian local populations and a corn synthetic population based on elite inbred lines. Bulletin of University of Agricultural Sciences and Veterinary Medicine Cluj-Napoca. Agriculture, 69(1),133-142.

Rozman, L. (2012). Genska banka koruze v Sloveniji. Acta agriculturae Slovenica, 99(3), 317-328.

Shelton, A.C., Tracy, W.F. (2015). Recurrent selection and participatory plant breeding for improvement of two organic open-pollinated sweet corn (Zea mays L.) populations. Sustainability, 7,5139-5152. doi:10.3390/su7055139 